\title{
Opinie studentów pedagogiki na temat swoich szkolnych nauczycieli
}

\section{Wprowadzenie}

Nauczyciel jest ważną osobą w życiu ucznia, jest przez niego spostrzegany przez sposób realizacji swojej roli zawodowej i przez indywidualne cechy. Student pedagogiki, podejmujący studia zebrał doświadczenia w kontaktach z nauczycielem z całego okresu szkolnego, aż do uzyskania matury. Utworzył sobie jego konkretny obraz. Ma szereg doświadczeń z własnego pobytu w szkole, uczestniczył w różnorodnych sytuacjach szkolnych. Z rówieśnikami i z rodziną wymieniał się opiniami na temat pracy swoich nauczycieli. Ma już pewne przekonania na temat roli nauczyciela, zwłaszcza, jeśli wybiera ten kierunek studiów. Niektórzy nauczyciele pozostali w jego pamięci jako ci, których cenił szczególnie, inni pozostawili po sobie niezbyt dobre wrażenie. Ten zestaw opinii dotyczący nauczycieli może stanowić podstawę do tworzenia obrazu nauczyciela w trakcie studiów, a potem również w jego rozwoju profesjonalnym. Można założyć, że początkowy sposób rozumienia roli nauczyciela będzie miał wpływ na przyjmowane przez kandydata na pedagoga treści z oferowanej mu na studiach wiedzy. W trakcie studiów te odczucia zostaną zmodyfikowane poprzez teoretyczne rozważania dotyczące oczekiwań wobec nauczyciela oraz opisu charakterystycznych sposobów realizacji przez nich swojej roli zawodowej, inaczej też będzie patrzył na nią jako praktykant. W niniejszym 
artykule postawiono pytanie - z jakim obrazem nauczyciela rozpoczynają studia absolwenci szkół, podejmujący studia pedagogiczne. Analizowano, jakie pozytywne i jakie negatywne cechy nauczyciela utkwiły w ich pamięci. Jakich nauczycieli cenią, a jacy wzbudzają w nich niechęć, które cechy powodują ich wysoką czy niską ocenę.

Studiujący kierunek pedagogika tworzą sobie pewien wzorzec roli nauczyciela i sposobów jego realizacji w praktyce, dlatego interesujący jest początkowy obraz nauczyciela, wyniesiony przez nich z okresu szkolnego. Badania przeprowadzono w pierwszych tygodniach studiów, kiedy studenci nie zdobyli jeszcze wiedzy teoretycznej z pedagogiki ani z pedeutologii, która mogła zmienić ich myślenie o zawodzie nauczyciela.

\section{Wzorzec roli nauczyciela a osobiste przekonania}

Podstawą indywidualnego wzorca roli nauczyciela są przekonania, przyjęte sposoby rozumienia świata, jakie posiada osoba wykonująca ten zawód. Mają one swoje źródła w indywidualnych teoriach wiedzy osobistej nauczycieli, rozwijających się w trakcie kształcenia zawodowego w szkole wyższej, wiedzy teoretycznej zdobywanej w ramach różnych przedmiotów kształcenia, doświadczeń w trakcie praktyk zawodowych. Henryka Kwiatkowska zauważa, że poznawana przez studentów wiedza jest filtrowana przez ich wiedzę zdroworozsądkową, potwierdzoną „przez doznane empiryczne fakty, życiowe zdarzenia”. „Jeśli wiedza poznawana w toku studiów odbiega od wiedzy zdroworozsądkowej, studentowi wydaje się nieprzydatna, oderwana od praktyki, zbyt teoretyczna"1. Omawiając poglądy Combsa na kształcenie nauczycieli, podkreśla, że „proces stawania się nauczycielem jest znaczony zasobem osobistych doświadczeń, z którymi student rozpoczyna przygotowanie zawodowe"2. Z tym faktem kształcenie nauczycieli musi się liczyć, ponieważ nie jest ono uczeniem się czegoś zupełnie nowego, lecz modyfikowaniem dotychczasowych przekonań. Po rozpoczęciu pracy w szkole, są one dalej korygowane na bazie własnych doświadczeń i przemyśleń. Mają na nie wpływ także opinie kolegów - nauczycieli,

\footnotetext{
$1 \quad$ H. Kwiatkowska, Pedeutologia, Wydawnictwa Akademickie i Profesjonalne, Warszawa 2008, s. 105.

2 Ibidem, s. 91.
} 
rozmowy z rodzicami uczniów i współpraca ze środowiskiem oraz pogłębiona refleksja nad własnym działaniem. Indywidualna teoria nauczyciela to „osobisty, dynamiczny system jego wiedzy na temat prawidłowości uczenia się i nauczania, roli ucznia i nauczyciela we wzajemnym współdziałaniu, będącej rezultatem dotychczasowych doświadczeń edukacyjnych nauczyciela i sposobu, w jaki ulegają one integracji w jego świadomości”3. Józefa Bałachowicz uważa, że z powstających w ten sposób indywidualnych, osobistych teorii, wynika styl kierowania klasą czy styl nauczania ${ }^{4}$. Czyli w zależności od sposobu rozumienia zjawisk pojawiających się w trakcie pracy, nauczyciel podejmuje takie a nie inne decyzje i wybiera określone sposoby działań. Od tego też będą zależały praktyki edukacyjne dominujące w jego pracy zawodowej oraz relacje nauczyciel-uczeń. Subiektywne odbieranie przez ucznia takich sposobów postępowania wyrabia jego opinię o nauczycielu, która również jest uwarunkowana sytuacją szkolną i osobistą oraz wymianą opinii z rówieśnikami i w środowisku rodzinnym. Uczniowie obserwują swoich nauczycieli, jedni są dla nich ważni i lubiani, inni nie stają się dla nich bliscy, boją się ich lub ich lekceważą. Warto się zastanowić, czy cechy swoich nauczycieli, których cenią najbardziej, chcieliby powielać sami jako nauczyciele. Podjęte badania mają odpowiedzieć na pytanie: jaki jest ten obraz, jakie opinie o swoich szkolnych nauczycielach formułują studenci rozpoczynający studia.

\section{Obraz nauczyciela i jego kompetencji w literaturze}

W literaturze pedagogicznej przedstawiono szereg kompetencji, jakimi powinien charakteryzować się nauczyciel. W zależności od przyjętego obrazu świata i sposobu widzenia roli nauczyciela ten zestaw kompetencji jest zróżnicowany. Robert Kwaśnica wyodrębnia we współczesnych analizach pedeutologicznych dwa kierunki rozważań na temat kompetencji nauczyciela ${ }^{5}$. Pierwszy z nich dotyczy kompe-

3 J. Bałachowicz, Style działań edukacyjnych nauczycieli klas początkowych, między uprzedmiotowieniem a podmiotowością, Wydawnictwo WSP TWP, Warszawa 2009, s. 155.

4 Ibidem, s. 159.

5 R. Kwaśnica, Wprowadzenie do myślenia o nauczycielu, [w:] Z. Kwieciński, B. Śliwerski, Pedagogika. Podręcznik akademicki, t. 2, Wydawnictwo Naukowe PWN, Warszawa 2007 , s. 299. 
tencji w zakresie praktyczno-moralnym, a w drugim mamy do czynienia z kompetencjami techniczno-analitycznymi.

Kompetencje praktyczno-moralne rozwijają w trakcie komunikowania się poprzez oferowanie możliwości dialogu. Nie polega on tylko na powstrzymywaniu się przed ingerowaniem w sposób myślenia innego człowieka, lecz na stwarzaniu warunków wypowiadania się we własnym imieniu, dając możliwość wypowiadania własnego zdania ${ }^{6}$. Ponieważ praca nauczyciela ma charakter komunikacyjny, zakres użycia kompetencji technicznych jest ograniczony do czynności związanych z wąsko pojętym nauczaniem. Są to czynności powtarzalne, realizowane na podobnym materiale. Natomiast oddziaływanie nauczyciela na ucznia $\mathrm{w}$ różnych konkretnych sytuacjach jest zwykle niestandardowe, jednostkowe, wynika z jego osobistej refleksji nad własnym działaniem? . Ta refleksja tworzy się w wyniku własnego doświadczenia, osobistego namysłu nad tym doświadczeniem, odwoływaniu się do zdobytej wiedzy naukowej w tym zakresie, dyskusji z osobami kompetentnymi, poszukiwaniem najlepszych rozwiązań w danej sytuacji praktycznej oraz tworzącymi się wskutek tego przekonaniami i własnymi sposobami postępowania pedagogicznego.

Do pierwszego rodzaju kompetencji nauczyciela Kwaśnica zalicza trzy grupy:

- kompetencje interpretacyjne, czyli takie, które pozwalają na rozumienie otaczającego świata i siebie samych, wizje świata uporządkowane i mające określony sens;

- kompetencje moralne - przyjęte zasady moralne normujące nasze postępowanie oraz stosunek do innych ludzi;

- na bazie tych kompetencji umiejętności komunikacyjne, jako możliwość bycia w dialogu z innymi, bez przemocy i narzucania uczestnikom dialogu swoich przekonań, równouprawnienie w dialogowym porozumiewaniu się ${ }^{8}$.

Niekiedy tę ostatnią umiejętność kwalifikuje się jako „sprawiedliwość zrównoważoną nauczyciela", przejawia się ona w uwzględnianiu w działaniach wobec wychowanka jego sytuacji, jednocześnie

\footnotetext{
$6 \quad$ Ibidem, s. 304-305.

$7 \quad$ J. Szymczak, Bycie (stawanie się) refleksyjnym nauczycielem. Perspektywa socjokulturowa, „Forum Dydaktyczne” 2009, nr 5-6, s. 51.

$8 \quad$ R. Kwaśnica, Wprowadzenie..., s. 299.
} 
zachowując określone, przyjęte przez nauczyciela wymagania. Zakłada ona szacunek dla ucznia, wyrozumiałość, wybaczanie błędów9.

W drugiego rodzaju kompetencjach techniczno-analitycznych Kwaśnica wyodrębnia:

- kompetencje postulacyjne (normatywne) - umiejętność identyfikowania się z celami założonymi w edukacji, wybór i tworzenie własnych celów zgodnych z konwencją;

- kompetencje metodyczne czyli umiejętność wykorzystania znanych sposobów działania, by osiągać założony cel (skuteczność działania) oraz tworzenie własnych metod na bazie oryginalnych, własnych pomysłów;

- kompetencje realizacyjne, jako umiejętność doboru środków, tworzenie warunków sprzyjających uczeniu się, organizowanie czasu pracy, efektywne wykorzystanie zastosowanych metod ${ }^{10}$.

W świetle założeń pedagogiki krytyczno-hermeneutycznej zakłada on, że kompetencje praktyczno-moralne mają w pracy nauczyciela pozycję nadrzędną. Wynika to ze swoistości tego zawodu, gdyż cele, metody i środki pedagogiczne nie mogą stać się narzędziem manipulacji i zniewalania drugiego człowieka. Oba rodzaje kompetencji rozwijają się w inny, specyficzny dla siebie sposób w trakcie stawania się nauczycielem. Kompetencje pierwszego typu nie mogą być ukształtowane w sposób monologowy - przekazujący wiedzę, tak jak można to uczynić w zakresie kompetencji technicznych ${ }^{11}$. Kompetencje praktyczno-moralnetworząsięwprocesiestawaniasięnauczycielemwwynikuwłasnych doświadczeń. Refleksja nad własnym działaniem pozwala mu na „stawanie się coraz doskonalszym, bardziej świadomym nauczycielem”12. Natomiast kompetencje techniczne mogą być nabyte poprzez prezentowanie odpowiedzi na pytania techniczne, językiem sprawozdawczym, wykładowym, ukazującym konkretne rozwiązania ${ }^{13}$.Zauważa się,

$9 \quad$ E. Ryś, Mądry nauczyciel - osoba silna duchem, [w:] J. Grzesiak (red.), Ewaluacje i innowacje $w$ edukacji. Kompetencje i odpowiedzialność nauczyciela, Uniwersytet Adama Mickiewicza w Poznaniu, Państwowa Wyższa Szkoła Zawodowa w Koninie, Kalisz - Konin 2010, s. 127.

10 R. Kwaśnica, Wprowadzenie..., s. 303.

11 Ibidem.

12 J. Szymczak, Bycie (stawanie się) refleksyjnym..., s. 51.

13 R. Kwaśnica, Wprowadzenie..., s. 305. 
że akademickie kształcenie nauczycieli w Polsce ma wyraźne ukierunkowanie na umiejętności techniczne.

Rzeczywista rola nauczyciela jest niejednorodna, zawiera w sobie zarówno elementy profesjonalne, wyraźnie wyznaczone przez ramy formalne, jednocześnie też nauczyciel pełni funkcję społeczną, dość niejasno określoną, ale ściśle związaną $\mathrm{z}$ tym zawodem. Powoduje to powiązanie życia osobistego z pracą zawodową i przenikanie się obu ról ${ }^{14}$. Może to też utrudniać życie osobiste, czy wywoływać konflikty, zwłaszcza, że w Polsce jest to zawód silnie sfeminizowany ${ }^{15}$. Rola społeczna nauczyciela, powiązana z jego zawodem, w różnych środowiskach może być inaczej rozumiana, co jeszcze bardziej utrudnia jej określenie.

\section{Nauczyciel w opinii studentów pedagogiki}

Badania dotyczące poglądów studentów pedagogiki obejmują zazwyczaj starsze roczniki. W swoich badaniach, dotyczących kompetencji nauczyciela, w odniesieniu do rozważań i podziału kompetencji Kwaśnicy, opinie studentów kierunku pedagogika trzeciego roku licencjatu i pierwszego roku studiów drugiego stopnia zebrali Mariusz Jabłoński i Józef Nawrocki ${ }^{16}$. Zauważyli, że studenci przewartościowują kompetencje techniczne $u$ nauczycieli, a kompetencje interpretacyjne i moralne uznali na ogół za mniej ważne. Natomiast kompetencje komunikacyjne, często wymieniane, traktowali dość jednokierunkowo, bardziej jako kompetencje techniczne, pozwalające na przekazywanie wiedzy i porozumiewanie się w sposób zrozumiały niż praktyczno-moralne o charakterze dialogowym ${ }^{17}$.

14 A. Gajdzica, Portret zbiorowy nauczycieli aktywnych - między zaangażowaniem a oporem wobec zmian, Wydawnictwo Adam Marszałek, Cieszyn - Toruń 2013, s. 127; K. Konarzewski, Nauczyciel, [w:] K. Konarzewski (red.), Sztuka nauczania, szkoła, Wydawnictwo Naukowe PWN, Warszawa 1995.

15 K. Konarzewski (red.), Sztuka nauczania..., s. 152-161.

16 M. Jabłoński, J. Nawrocki, Kompetencje pedagogiczne nauczyciela jako podstawowa wartość w kształtowaniu relacji między wychowankiem i wychowawcą, [w:] J. Grzesiak (red.), Ewaluacje i innowacje w edukacji. Kompetencje $i$ odpowiedzialność nauczyciela, Uniwersytet Adama Mickiewicza w Poznaniu, Państwowa Wyższa Szkoła Zawodowa w Koninie, Kalisz - Konin 2010, s. 86.

Ibidem, s. 87. 
Badanie opinii studentów na temat pedagoga (absolwenta pedagogiki, kierunki nienauczycielskie) opisała Danuta Urbaniak-Zając ${ }^{18}$. Badała studentów 8 semestru pedagogiki, o specjalności profilaktyka i animacja kulturalna. Anonimowe wypowiedzi studentów na pytanie o zawód pedagoga, pisane w czasie zajęć, ale całkowicie dobrowolne, posłużyły jej do analizy jakościowej. Spośród nich badająca przypadkowo wybrała jeden protokół, który był podstawą szczegółowej analizy (zgodnie z „obiektywną hermeneutyką" Oevermanna). Przyjęła, że przedstawia on społeczny sposób widzenia zawodu przez studentów, a wyobrażenie pracy pedagoga jest prawdopodobnie efektem doświadczeń akademickich. Omawiając strukturę tego przypadku, zauważyła, że przedmiotem opisu jest osoba, a nie sam zawód. Opisywana osoba ma odpowiednią wiedzę i praktyczne umiejętności, w które została wyposażona (z zewnątrz). To stanowi jej umiejętność działania oraz uprawnienia formalne do wykonywania określonych czynności ${ }^{19}$. Treść tych zasobów jest ustalana poza nim (uprzedmiotowienie pedagoga). Jednocześnie musi on mieć „szerokie horyzonty myślowe” i „być otwarty na drugą osobę” "umieć komunikować się z nią” (cechy osobowe pedagoga). Badająca zauważa dwoistość rozumienia roli pedagoga, lecz podkreśla, że student/studentka nie zauważa roli nauczyciela jako kreatora własnego zawodu, raczej przypisuje mu pewne cechy wrodzone (np. godny zaufania) oraz ukształtowane (zewnętrznie) w czasie nauki - narzędzia oddziaływania na innych ${ }^{20}$.

Te spostrzeżenia pozwalają postawić hipotezę, że osobowy wymiar pracy nauczyciela przestaje mieć dominujące znaczenie w trakcie studiów pedagogicznych. Zaawansowani studenci przykładają znaczenie do formalnych i technicznych kompetencji nauczyciela. Jednak początkujący studenci mogą inaczej spostrzegać cechy swoich nauczycieli.

\footnotetext{
18 D. Urbaniak-Zając, Obraz zawodu pedagoga kształtujący się u studentów kierunku pedagogika - przykład zastosowania obiektywnej hermeneutyki, [w:] D. Urbaniak-Zając, E. Kos (red.), Badana jakościowe w pedagogice, Wywiad narracyjny i obiektywna hermeneutyka, Wydawnictwo Naukowe PWN, Warszawa 2014, s. 331. 


\section{Przebieg i analiza badań własnych}

Studentom pierwszego roku pedagogiki, zadano otwarte pytania: jakiego nauczyciela ceniłeś najbardziej? Jakiego nauczyciela ceniłeś najmniej? Ponadto dodano szczegółowe punkty - poziom edukacji, w którym ten nauczyciel uczył, jego wiek, wygląd i osobowość, przygotowanie merytoryczne, stosunek do uczniów i rodziców oraz inne charakterystyczne cechy. Ten sondaż diagnostyczny przeprowadzono na sali audytoryjnej, w formie pisemnej, anonimowej wypowiedzi wraz z dołączoną metryczką. Dane dotyczące miejsca zamieszkania i tryb studiowania badanych przedstawia tabela 1.

Tabela 1. Dane o grupie badanych

\begin{tabular}{|l|c|c|c|c|c|c|}
\hline \multirow{2}{*}{$\begin{array}{c}\text { Miejscowośćc } \\
\text { rodzinna }\end{array}$} & \multicolumn{2}{|c|}{$\begin{array}{c}\text { Studenci } \\
\text { stacjonarni }\end{array}$} & \multicolumn{2}{c|}{$\begin{array}{c}\text { Studenci } \\
\text { niestacjonarni }\end{array}$} & \multicolumn{2}{c|}{ Razem } \\
\cline { 2 - 7 } & $\mathbf{N = 7 0}$ & $\mathbf{0}$ & $\mathbf{N}=\mathbf{3 3}$ & $\mathbf{\%}$ & $\mathbf{N}$ & $\mathbf{\%}$ \\
\hline Wieś & 24 & 34,3 & 14 & 42,4 & 38 & 36,9 \\
\hline Małe miasto & 20 & 28,6 & 13 & 39,4 & 33 & 32,0 \\
\hline Duże miasto & 8 & 11,4 & 3 & 9,1 & 12 & 11,6 \\
\hline Wielkie miasto & 16 & 22,9 & 3 & 9,1 & 19 & 18,4 \\
\hline Razem & $\mathbf{6 8}$ & $\mathbf{9 7 , 1}$ & $\mathbf{3 3}$ & $\mathbf{1 0 0 , 0}$ & $\mathbf{1 0 1}$ & $\mathbf{9 8 , 0}$ \\
\hline
\end{tabular}

Źródło: badania własne.

Przeanalizowano opinie 103 studentów pedagogiki (1 semestr studiów licencjackich, jeszcze bez wyboru specjalności), były to 102 kobiety i 1 mężczyzna. 36 osób miało nauczyciela w rodzinie (34\%), studenci studiów stacjonarnych częściej $(42,9 \%)$ niż studenci studiów niestacjonarnych (18,2\%). Wiek badanych to 18-21 lat, 5 osób było trochę starszych (powyżej 25 roku życia).

Studenci wymieniali najczęściej nauczycieli ze szkoły średniej (zarówno tych cenionych, jak i mniej cenionych), studenci niestacjonarni nieco więcej wymienili nauczycieli gimnazjum, jako tych cenionych.

Jako najbardziej cenionych najczęściej wymieniono polonistów (36 osób) i matematyków (26), nauczycieli języków obcych (10), ale też WOS (5), historii (5) i innych. Jako najmniej cenionych wymieniano głównie matematyków (29), polonistów (10), historyków (15), w-f (7), tutaj opinie były bardziej rozproszone. Wiek i płeć nie różnicowały 
Tabela 2. Szkoła, w której uczyli opisywani nauczyciele

\begin{tabular}{|l|c|c|c|c|c|c|c|c|}
\hline \multirow{2}{*}{ Ocena nauczycieli } & \multicolumn{2}{|c|}{$\begin{array}{c}\text { Szkoła } \\
\text { podstawowa }\end{array}$} & \multicolumn{2}{|c|}{ Gimnazjum } & \multicolumn{2}{c|}{$\begin{array}{c}\text { Szkoła } \\
\text { średnia }\end{array}$} & \multicolumn{2}{|c|}{ Razem } \\
\cline { 2 - 9 } & $\mathbf{N}$ & $\mathbf{\%}$ & $\mathbf{N}$ & $\mathbf{\%}$ & $\mathbf{N}$ & $\mathbf{\%}$ & $\mathbf{N}$ & $\mathbf{\%}$ \\
\hline $\begin{array}{l}\text { Nauczyciele } \\
\text { cenieni najbardziej }\end{array}$ & 10 & 9,7 & 19 & 18,5 & 74 & 71,8 & 103 & 100 \\
\hline $\begin{array}{l}\text { Nauczyciele } \\
\text { cenieni najmniej }\end{array}$ & 12 & 11,6 & 19 & 18,5 & 69 & 67,0 & 100 & 97,1 \\
\hline Razem opinii & 22 & 10,1 & 38 & 18,7 & 143 & 70,4 & 203 & 100 \\
\hline
\end{tabular}

Źródło: badania własne.

nauczycieli cenionych i niecenionych; wymieniono tu podobną liczbę osób (najwięcej w wieku 36-50 lat - odpowiednio 55 osób i 49 oraz po 23 mężczyzn i odpowiednio 80 i 77 kobiet). Liczby te odpowiadają statystyce dotyczącej populacji nauczycieli. Nie zauważono istotnych różnic w opinii o nauczycielach danej płci czy w danym wieku.

Postawiono następujące pytanie badawcze: Czym charakteryzują się nauczyciele, którzy zostali zapamiętani jako ci, których cenili najbardziej, a jakie cechy mają ci, których studenci nie cenili?

Zastanawiano się, jakie są to cechy w świetle opisu kompetencji nauczyciela. Jako podstawę analizy zebranych wypowiedzi przyjęto dwa rodzaje kompetencji wyróżnionych przez Roberta Kwaśnicę ${ }^{21}$.

Studenci w różny sposób opisywali nauczycieli, jedni przywoływali kilka określeń, opisywali zachowania, sposób pracy, inni używali tylko pojedynczych przymiotników. Starano się ocenić całość wypowiedzi respondenta i wyodrębnić, co w niej dominowało (wnikać w znaczenie tych określeń). Próbowano zaklasyfikować te wypowiedzi jako opinie dotyczące trzech grup znaczeń: głównie technicznych kompetencji nauczycieli, z większym naciskiem na kompetencje moralno-praktyczne lub obu w zrównoważonym stopniu.

Do pierwszego typu technicznych kompetencji, przykładowo, zaliczono $^{22}$ :

- opinie pozytywne: potrafiła dokładnie przekazać wiedzę (nr 32), wiedza wykraczała poza książkową (35), była starannie przygo-

21 R. Kwaśnica, Wprowadzenie...

22 W nawiasie podano numer protokołu. 
towana, dodatkowe materiały (17), idealnie tłumaczyła zadania matematyczne (48), cenne wskazówki do nauki w domu (75), uczyła zrozumiale, miała cierpliwość do uczniów (24), potrafiła dokładnie przekazać nam wiedzę z geografii (32), imponująca wiedza (99), dobrze przygotowała do matury (41), chęć rozwijania pasji z zakresu sportu (36), idealnie tłumaczył zadania matematyczne (48);

- opinie negatywne: nikt nie wiedział, co ma umieć (nr 23), wszystko czytał z Internetu (53), siedziała tylko przy biurku i dyktowała z podręcznika (42), była nieprzygotowana, mówiła nie na temat (32), gubiła się w zadaniach (16), był bardzo dobrze przygotowany merytorycznie, nie potrafił wytłumaczyć obrazowo, cały czas pisał na tablicy, odwracał się, pytał czy rozumiemy, mówiliśmy „nie”, ale on szedł dalej (9), spóźniał się, nie był przygotowany (17), zajęcia prowadzone za szybko, pomijał materiał (100), nie oczekiwała żadnej informacji zwrotnej (88).

Do drugiego typu, praktyczno-moralnych kompetencji nauczyciela, zaliczono wypowiedzi:

- pozytywne: dobrze zorganizowana, zdyscyplinowana, sprawiedliwa i wymagająca, otwarta, dobra, spokojna (nr 31), miała dystans do siebie, często z nami żartowała (63), wymagająca, a jednocześnie bardzo sympatyczna i pomocna (67), zawsze miała czas dla uczniów, czy to chodziło o przedmiot, czy też problemy rodzinne (30);

- negatywne: czasami wredna, niesprawiedliwie oceniająca (nr 48), traktowała wszystkich po znajomości (54), wulgarna (21), faworyzowanie bogatych (41), poniżała na forum klasy (63), agresywna, kpiąca, dręcząca, obelżywa (64), uważał nas za bezmózgowców (37), traktowała nas jak śmiecie (47), mściwa, mówiła tylko o złych cechach uczniów (45), skoncentrowany tylko na sobie (27), rygorystyczna, kłótliwa (29), zawsze wiedziała lepiej (4), zbyt ulegała uczniom (8).

Pewną część wypowiedzi można było zaliczyć do pierwszego lub drugiego typu wypowiedzi, ale starano się je ocenić w świetle całości opinii. Było też sporo wypowiedzi, które zawierały oba te elementy w miarę zrównoważone ${ }^{23}$.

23 Patrz tabela 3. 
W opiniach o nauczycielu można było też znaleźć opis cech osobistych, wiążących się nie tyle z rolą zawodową, co społeczną nauczyciela. Były to wypowiedzi takie, jak:

- w opiniach pozytywnych: charyzmatyczny, przyciągał uwage (nr 62), wytatuowana (76), ubrana tylko w odcienie szarości (85), zadbana, wysportowana (39), papieros w ustach w palarni, zapach dymu, fikuśne kamizelki (34);

- w opiniach negatywnych: ubierała się wyzywająco (nr 13), elegancka, zadbana, miała stare metody wychowawcze (83), bezgustowna (80), dystyngowana, zarozumiała (56), alkoholiczka (7), ciągle spocona, czuć było alkohol (14), zasypiała na lekcjach (49), jadła na lekcji (18), wegetarianin, chudy, nosił sandały (69), kobieta z czerwonymi ustami, niemiła (90).

Tabela 3. Porównanie rodzaju kompetencji wymienianych w opiniach o nauczycielu najbardziej i najmniej cenionym

\begin{tabular}{|l|c|c|c|c|c|c|c|c|}
\hline \multirow{2}{*}{$\begin{array}{c}\text { Ocena } \\
\text { nauczycieli }\end{array}$} & \multicolumn{2}{|c|}{$\begin{array}{c}\text { Kompetencje } \\
\text { techniczne }\end{array}$} & $\begin{array}{c}\text { Kompetencje } \\
\text { moralno- } \\
\text {-praktyczne }\end{array}$ & \multicolumn{2}{|c|}{$\begin{array}{c}\text { Zrów- } \\
\text { noważona } \\
\text { ocena }\end{array}$} & \multicolumn{2}{|c|}{ Razem } \\
\cline { 2 - 9 } & $\mathbf{N}$ & $\mathbf{\%}$ & $\mathbf{N}$ & $\mathbf{\%}$ & $\mathbf{N}$ & $\mathbf{\%}$ & $\mathbf{N}$ & $\mathbf{\%}$ \\
\hline $\begin{array}{l}\text { Nauczyciele } \\
\text { cenieni } \\
\text { najbardziej }\end{array}$ & 32 & 31,1 & 50 & 48,6 & 21 & 20,4 & 103 & 100 \\
\hline $\begin{array}{l}\text { Nauczyciele } \\
\text { cenieni najmniej }\end{array}$ & 24 & 23,3 & 71 & 68,9 & 5 & 4,9 & 100 & 97 \\
\hline
\end{tabular}

Źródło: badania własne.

W powyższych zestawieniach można zauważyć, że wyraźnie dominują opinie biorące pod uwagę kompetencje moralno-praktyczne, dotyczy to zarówno opisu nauczyciela cenionego, jak też nauczyciela najmniej cenionego.

Kompetencje techniczne w postaci dobrej organizacji pracy, przygotowania ciekawych materiałów, dobrego przekazywania wiedzy, zachęcania do uczenia się, zrozumiałego tłumaczenia były znacznie rzadziej wymieniane przez badanych, niż takie cechy jak sprawiedliwość, wyrozumiałość, dobry kontakt, wspieranie uczniów, otwartość i swoboda w kontakcie. Podkreślano umiejętność rozładowywania konfliktów, żartowania oraz zachowanie spokoju, jasno sformułowane 
wymagania, panowanie nad klasą. Ceniono sobie ułatwienie kontaktu poprzez dostęp do maila lub telefonu, zaufanie do nich. Niekiedy niektóre osobiste cechy negatywne (np. palenie papierosów) nie przekreślały pozytywnej opinii o nauczycielu.

W odniesieniu do nauczycieli najmniej cenionych studenci jeszcze częściej użyli określeń wskazujących na braki w ich kompetencjach moralno-praktycznych. Opinie badanych przede wszystkim skupiły się na złym traktowaniu uczniów, tworzeniu niemiłej atmosfery, złym kontakcie z uczniami. Bardzo często podkreślano niesprawiedliwość, faworyzowanie niektórych uczniów, ale też wywyższanie się, obrażanie, brak zrozumienia. Pojawiły się określenia wskazujące na obojętność na sprawy ucznia, brak szacunku dla niego, lekceważenie jego zdania, narzucanie uczniom swoich przekonań, straszenie ich negatywną przyszłością, stwierdzając, że źle skończą. Negatywnie też oceniano nadmierny rygoryzm i ścisłe trzymanie się wyznaczonego trybu.

Niewielka grupa studentów próbowała równoważyć obie grupy cech, ale dotyczyło to jedynie nauczycieli cenionych, w odniesieniu do najmniej cenionych, taka zrównoważona ocena była rzadkością. Wygląd zewnętrzny nauczyciela na ogół opisują dość schematycznie (kolor włosów, sylwetkę). Niekiedy podkreślają elegancję lub szczególne cechy (dbałość o zdrowie, wysportowanie lub niezwykłą odzież czy biżuterię).

Nie zauważono istotnych związków tych opinii ze środowiskiem pochodzenia studentów, trybem studiowania, czy osobą nauczyciela w rodzinie.

\section{Podsumowanie}

Uczniowie obserwują swoich nauczycieli, jedni są dla nich ważni i lubiani, inni nie stają się dla nich bliscy, boją się ich lub ich lekceważą. Warto przyjrzeć się, jaki obraz nauczyciela pozostaje w umyśle absolwenta szkoły.

Na podstawie analizowanych opinii można utworzyć obraz nauczyciela cenionego przez uczniów. Jest to osoba na ogół:

- merytorycznie dobrze przygotowana, wiedza i umiejętności nauczyciela są traktowane przez ucznia jako rzecz oczywista, nie jest ona specjalnie przez niego analizowana;

- jako istotna cecha wymieniana jest umiejętność panowania nad uczniami i materiałem nauczania; 
- bardzo ważny jest dla badanych dobry stosunek nauczyciela do swoich podopiecznych, zwłaszcza dobry kontakt i rozumienie sytuacji ucznia, sprawiedliwe ocenianie jego osiągnięć oraz inicjatywy i zaangażowania;

- zauważana jest bliskość i wzajemne zaufanie, chęć kontaktu i wspieranie wysiłków ucznia;

- dodatkowo ceniony jest dystans do siebie, poczucie humoru w skomplikowanych sytuacjach.

Dużo gorzej oceniana jest osoba nauczyciela, która jest:

- słaba merytorycznie, a jeśli nawet jej wiedza jest wysoka, to nie liczy się z możliwościami uczniów, wywyższa się, okazuje pogardę dla ich możliwości;

- poniża uczniów, obraża ich, ciągle krytykuje, wtrąca się, dręczy, jest złośliwa;

- wyraźnie faworyzuje niektórych uczniów (bogatych, znajomych, lepszych w sporcie, chłopców);

- niesprawiedliwie ocenia, mści się za wszelkie psikusy, nie docenia ich wysiłku;

- jest obojętna dla spraw ucznia i dba tylko o własne korzyści.

$\mathrm{Na}$ podstawie uzyskanych wyników badań można wyprowadzić dość jednoznaczne wnioski.

Opis nauczyciela przygotowany przez studentów pierwszego roku, rozpoczynających studia pedagogiczne, jest dokonywany głównie pod kątem jego kompetencji moralno-praktycznych. Badani uważają te cechy nauczyciela za bardziej znaczące, ważniejsze dla jego scharakteryzowania niż techniczne umiejętności prowadzenia zajęć i wiedzę zawodową.

Dominacja kompetencji technicznych w obrazie nauczyciela czy pedagoga, rysowanym przez studentów starszych lat, jak wynika $\mathrm{z}$ analizowanej literatury, powstaje w trakcie studiów, pod wpływem nabywanej wiedzy pedagogicznej.

Podobnie uważa w swoich refleksjach o nauczycielu R. Kwaśnica. Stwierdza, że w opisie polskiego nauczyciela w literaturze pedagogicznej dominuje ,jednobarwny obraz nauczyciela jako wykonawcy, który nie dostrzegając innych problemów poza technicznymi, redukuje swój rozwój do doskonalenia kompetencji technicznych (metodycznych)"24.

24 R. Kwaśnica, Wprowadzenie..., s. 312. 
Oczekuje więc od przygotowania zawodowego jedynie technicznych wskazówek.

Warto zastanowić się, czy nie należałoby wcześnie podjąć działań wobec studentów, które uświadomiłyby im własne spostrzeżenia i na tych osobistych opiniach budować obraz kompetencji nauczyciela, aby lepiej rozumieli oni wartość kompetencji moralno-praktycznych i nie przeszacowywali ważności kompetencji technicznych. Wtedy może znacznie więcej uwagi przywiązywaliby do własnego rozwoju osobistego w trakcie studiów pedagogicznych.

\begin{abstract}
The article reviews the opinions of beginning pedagogy students. They were asked about their school teachers, those who they valued the most and the least. Students mainly described their moral and practical competences. Students appreciate the most the ability to establish rapport and to communicate and deal with students. According to the critical-hermeneutic theory, these competences have the greatest impact on the students, but they are difficult to teach during professional training. Making students aware of this can increase their inclination to develop their social skills.
\end{abstract}

\title{
Bibliografia
}

Bałachowicz J., Style działań edukacyjnych nauczycieli klas początkowych, między uprzedmiotowieniem a podmiotowościa, Wydawnictwo WSP TWP, Warszawa 2009.

Gajdzica A., Portret zbiorowy nauczycieli aktywnych - między zaangażowaniem a oporem wobec zmian, Wydawnictwo Adam Marszałek, Cieszyn - Toruń 2013, s. 127.

Jabłoński M., Nawrocki J., Kompetencje pedagogiczne nauczyciela jako podstawowa wartość $w$ ksztaltowaniu relacji między wychowankiem $i$ wychowawca, [w:] J. Grzesiak (red.), Ewaluacje i innowacje w edukacji. Kompetencje i odpowiedzialność nauczyciela, Uniwersytet Adama

Mickiewicza w Poznaniu, Państwowa Wyższa Szkoła Zawodowa w Koninie, Kalisz - Konin 2010.

Konarzewski K., Nauczyciel, [w:] K. Konarzewski (red.), Sztuka nauczania, szkoła, Wydawnictwa Naukowe PWN, Warszawa 1995.

Kwaśnica R., Wprowadzenie do myślenia o nauczycielu, [w:] Z. Kwieciński, B. Śliwerski, Pedagogika. Podręcznik akademicki, t. 2, Wydawnictwo Naukowe PWN, Warszawa 2007. 
Kwiatkowska H., Pedeutologia, Wydawnictwa Akademickie i Profesjonalne, Warszawa 2008.

Ryś E., Mądry nauczyciel - osoba silna duchem, [w:] J. Grzesiak (red.), Ewaluacje $i$ innowacje w edukacji. Kompetencje $i$ odpowiedzialność nauczyciela, Uniwersytet Adama Mickiewicza w Poznaniu, Państwowa Wyższa Szkoła Zawodowa w Koninie, Kalisz - Konin 2010.

Szymczak J., Bycie (stawanie się) refleksyjnym nauczycielem. Perspektywa socjokulturowa, „Forum Dydaktyczne” 2009, nr 5-6.

Urbaniak-Zając D., Obraz zawodu pedagoga kształtujący się u studentów kierunku pedagogika - przykład zastosowania obiektywnej hermeneutyki, [w:] D. Urbaniak-Zając, E. Kos (red.), Badana jakościowe $w$ pedagogice, Wywiad narracyjny i obiektywna hermeneutyka, $\mathrm{Wy}^{-}$ dawnictwo Naukowe PWN, Warszawa 2014. 